\title{
Enhancement in extraction of boron and phosphorus from metallurgical grade silicon by copper alloying and aqua regia
}

\section{leaching}

Liuqing Huang ${ }^{\mathrm{a}}$, Huixian Lai ${ }^{\mathrm{a}}$, Chenghao Lu ${ }^{\mathrm{a}}$, Ming Fang ${ }^{\mathrm{a}}$,Wenhui Ma ${ }^{\mathrm{b}}$, Pengfei

$\mathrm{Xing}^{\mathrm{c}}$, Jintang $\mathrm{Li}^{\mathrm{a}}$ and Xuetao $\mathrm{Luo}^{\mathrm{a}, *}$

a Fujian Key Laboratory of Advanced Materials, College of Materials, Xiamen University, Xiamen 361005, P R China

${ }^{\mathrm{b}}$ Faculty of Materials and Metallurgical Engineering, Kunming University of Science and Technology, Kunming 650093, P R China

${ }^{c}$ School of Materials and Metallurgy, Northeastern University, Shenyang 110004, P R China

${ }^{*}$ Corresponding author: Xuetao Luo (E-mail: xuetao@xmu.edu.cn, Tel: +86-592-2188503) 


\section{Abstract:}

The feasibility and optimization of an enhanced boron and phosphorus extraction process, from metallurgical grade silicon (MG-Si), consisting of solvent refining and acid leaching were studied comprehensively. MG-Si was alloyed with copper $(\mathrm{Cu})$, following which, the removal of boron and phosphorus from the $\mathrm{Si}-\mathrm{Cu}$ alloy by acid leaching was investigated. The results showed that the $\mathrm{Cu}$-alloying process led to the concentration of boron and phosphorus in the $\mathrm{Si}-\mathrm{Cu}$ alloy phase, which was confirmed to be an important part of their removal. Based on the analysis of acid sensitivity of the $\mathrm{Si}-\mathrm{Cu}$ alloy phase, it was found that aqua regia was an effective leaching agent for removing the $\mathrm{Si}-\mathrm{Cu}$ alloy phases from $\mathrm{Si}$ grains compared to $\mathrm{HCl}$ and $\mathrm{HNO}_{3}$. Addition of copper resulted in the increase in the extraction yield of boron and phosphorus from MG-Si from 21.0 to $58.7 \%$ and 23.2 to $42.2 \%$, respectively. The selected $\mathrm{Si}-\mathrm{Cu}$ powders were within a size range $74-106 \mu \mathrm{m}$ and the leaching was conducted at $70{ }^{\circ} \mathrm{C}$ for $5 \mathrm{~h}$ via a three-step sequential acid leaching procedure. Furthermore, the leaching kinetics of boron and phosphorus using aqua regia was observed to be controlled by interfacial transfer and product layer diffusion.

Keywords: metallurgical grade silicon; silicon-copper alloy; aqua regia; leaching; kinetics. 


\section{Introduction}

Solar energy is the most abundant and clean source of renewable energy. With the development of the photovoltaic industry, the production of solar cells is increasing rapidly. By far, the most prevalent bulk material for solar cells is crystalline silicon (c-Si), also known as solar grade Si. Over $80 \%$ of solar cells are made of polycrystalline Si (Braga et al., 2008). Polycrystalline Si cells are less expensive, yet less efficient than those made from monocrystalline Si (Lee et al., 2015). Recently, an increased interest in environmental protection and a reduction of manufacturing prices have urged the countries to explore more practical and economical methods. Thus, metallurgical purification methods for the production of solar grade Si have been introduced (Mukashev et al., 2009). These methods include acid leaching (Sakata et al., 2002), solvent refining (Yoshikawa and Morita, 2012), vacuum refining (Zheng et al., 2011), and slag treatment (Jung et al., 2014), etc.

Noteworthy, the impurity distribution depends on the segregation behavior of impurities in metallurgical grade $\mathrm{Si}$ (MG-Si), which directly affects their subsequent extraction. The metallic impurities, such as iron $(\mathrm{Fe})$, aluminum $(\mathrm{Al})$, and calcium $(\mathrm{Ca})$, are primary located at the $\mathrm{Si}$ grain boundaries or the grain surfaces owing to their small segregation coefficients (Tan et al., 2014). Nonmetallic impurities, namely boron (B) and phosphorus (P), gather inside the $\mathrm{Si}$ grain with high segregation coefficient, which restricts their exposure to the acid or removal by directional solidification (Jiang et al., 2014; Sim et al., 2006). Therefore, slag treatment has been proposed to remove $\mathrm{B}$ via oxidation reactions and $\mathrm{P}$ can be removed from molten $\mathrm{Si}$ 
by vacuum refining based on vapor pressure difference. However, these methods involve rigorous equipment requirements and high energy consumption. Thus, the removal of $\mathrm{B}$ and $\mathrm{P}$ from $\mathrm{MG}-\mathrm{Si}$ has remained a challenging task.

Solvent refining, a purification process has been employed to overcome the above mentioned barriers. In this process, $\mathrm{Si}$ recrystallization takes place from the supersaturated melt depending on the segregation behavior of impurities (Hu et al., 2013). Given the low melting points and low segregation coefficients of the impurities present between the solid $\mathrm{Si}$ and the alloy melt, metals such as $\mathrm{Al}, \mathrm{Fe}$, tin ( $\mathrm{Sn})$, and copper $(\mathrm{Cu})$ are typically used as impurity getters (Li et al., 2014; Ma et al., 2013). In our study, $\mathrm{Cu}$ was selected as the impurity getter due to its low solubility in the solid silicon and the large difference in their densities (Olesinski and Abbaschian, 1986). The main problem involved in solvent refining is the difficulty in separating primary Si and solvent metal. Conventional separation methods involve gravity sedimentation (Mitrasinovic and Utigard, 2009) and electromagnetic force (Yoshikawa and Morita, 2005). The gravity separation method is suitable for systems in which there is a large density difference between $\mathrm{Si}$ and solvent, such as the $\mathrm{Si}-\mathrm{Cu}$ and $\mathrm{Si}-\mathrm{Fe}$ systems. In the study of Morita et al., an electromagnetic field was applied to separate Si crystals grown from a $\mathrm{Si}-\mathrm{Al}$ melt during solidification. These methods have their own disadvantages, such as low efficiency and limited effect on removal of small inclusions. However, acid leaching is a feasible and low-cost method for refining MG-Si at the industrial scale. Several researchers have reported that alloying followed by acid leaching is an effective route to purify MG-Si. Recently, alloying with 
titanium (Ti) or Ca followed by acid leaching was found to significantly improve the removal efficiency of B and P from MG-Si. Shimpo et al. melted Si-P-Ca alloy and then leached using aqua regia, it was found that $80 \% \mathrm{P}$ was removed by the addition of 5.17 at\% Ca (Shimpo et al., 2004). Yoshikawa et al. used $\mathrm{Ti}$ as an additive to remove $\mathrm{B}$ from $\mathrm{Si}-\mathrm{Al}$ alloy, and then leached with a mixture of $\mathrm{HCl}+\mathrm{HNO}_{3}+\mathrm{H}_{2} \mathrm{SO}_{4}$ (Yoshikawa et al., 2005). Johnston et al. studied Ti and Ca metals as impurity getters in purification of MG-Si, focusing on the removal of $\mathrm{B}$ and $\mathrm{P}$ (Johnston and Barati, 2013). In addition to $\mathrm{Ti}$ and $\mathrm{Ca}$, other metal elements have been investigated as well. Margarido et al. studied the refining of Si-Fe alloy using a two-step leaching procedure: first stage involved the use of $\mathrm{HCl}$ and the second stage employed $\mathrm{HCl}+\mathrm{FeCl}_{3} \cdot 6 \mathrm{H}_{2} \mathrm{O}$. The leaching of main metallic impurities $(\mathrm{Fe}, \mathrm{Al}$, and $\mathrm{Ca}$ ) was found to depend on the composition of the phases and nature of their distribution (Margarido et al., 1993). Visnovec et al. used a mixture of $\mathrm{HNO}_{3}+\mathrm{HCl}$ to purify $\mathrm{Si}-\mathrm{Cu}$ alloy after gravity separation. It was determined that the overall impurity level in purified $\mathrm{Si}$ was reduced from 5277 to $225.5 \mathrm{ppmw}$ (Visnovec et al., 2012). Although, these studies have been conducted for removing impurities by the addition of above mentioned elements, the corresponding mechanisms contributing to a higher removal efficiency of $\mathrm{B}$ and $\mathrm{P}$ have been rarely touched. Furthermore, little attention has been paid in literature to the investigation of the effect of lixiviant on the separation and purification of alloy phase during leaching process.

The main objective of the current study was to demonstrate that $\mathrm{Cu}$ alloying in combination with acid leaching could be effectively used for purifying MG-Si, in 
particular, for removing $\mathrm{B}$ and $\mathrm{P}$. In this study, MG-Si was first alloyed with $\mathrm{Cu}$ to trap $\mathrm{B}$ and $\mathrm{P}$, and then the purified $\mathrm{Si}$ was recovered by acid leaching. Various parameters of the process including particle size of the alloy powder, leaching reagent, time, and temperature were comprehensively studied. Moreover, a modified cracking shrinking model was applied to analyze the acid leaching kinetics.

\section{Materials and methods}

\subsection{Materials}

The raw material, MG-Si lumps, with a purity of $99 \%$ was provided by Run Xiang Co., Ltd., China. The contents of the main impurities in MG-Si are listed in Table 1. $\mathrm{Cu}$ powders (particle size: 74-106 $\mu \mathrm{m}$ ) and reagent-grade $\mathrm{HCl}, \mathrm{HNO}_{3}$, and $\mathrm{HF}$ were purchased from Sinopharm Chemical Reagent Co., Ltd. The initial MG-Si and the prepared $\mathrm{Si}-50 \mathrm{wt} . \% \mathrm{Cu}$ alloy were crushed to a size of $<1 \mathrm{~mm}$ by jaw and roll crushers, respectively. Then, five particle size ranges were selected by sieving: $0-74$, 74-106, 106-149, 149-178, and $>178 \mu \mathrm{m}$. The MG-Si powders with a particle size of $<1 \mathrm{~mm}$ were used in the preparation of $\mathrm{Si}-50 \mathrm{wt} . \% \mathrm{Cu}$ alloy. The MG-Si powders with a particle size of 74-106 $\mu \mathrm{m}$ were used in the acid leaching experiments.

\section{Table 1}

\subsection{Alloying and Solidification Process}

Fig. 1(a) shows a sketch of apparatus used in this process. For the preparation of $\mathrm{Si}-50$ wt.\% $\mathrm{Cu}$ alloy, MG-Si powders (particle size: $<1 \mathrm{~mm}$ ) were mixed with $\mathrm{Cu}$ powders to form the mixture of $\mathrm{Si}-50 \mathrm{wt} . \% \mathrm{Cu}(\mathrm{MG}-\mathrm{Si} / \mathrm{Cu}$ mass ratio $=1: 1)$. The mixture was then melted in a tube furnace (total alloy mass of $\sim 100 \mathrm{~g}$ ). For this, the 
mixture was heated to $1550{ }^{\circ} \mathrm{C}$ at the rate of $5{ }^{\circ} \mathrm{C} \cdot \mathrm{min}^{-1}$ in an argon atmosphere, and then held for $2 \mathrm{~h}$ to allow for homogenization of the melt. The temperature was continuously measured using a WRe5-WRe26 thermocouple and was controlled within $\pm 10 \mathrm{~K}$. The mixture was subsequently cooled at a rate of $5^{\circ} \mathrm{C} \cdot \mathrm{min}^{-1}$.

\subsection{Acid Leaching}

As shown in Fig. 1(b), ten gram samples of $\mathrm{MG}-\mathrm{Si}$ and $\mathrm{Si}-50$ wt.\% $\mathrm{Cu}$ alloy powders were mixed with $100 \mathrm{~mL}$ of leachant in a Teflon beaker with mechanical stirring, respectively. The extraction was done via a three-step sequential acid leaching procedure:

Step 1: $2 \mathrm{M} \mathrm{HCl} / \mathrm{HNO}_{3}$ / aqua regia

Step 2: $2 \mathrm{M} \mathrm{HNO}_{3}+$ trace $\mathrm{HF}$

\section{Step 3: $1 \mathrm{M} \mathrm{HNO}_{3}$}

The experimental variables included the leaching reagent (used in the first step), particle size, time, and temperature. After acid leaching, the solution was filtered and rinsed thoroughly with de-ionized water until the solution was neutral and then it was dried.

\section{Fig. 1}

\subsection{Characterization}

Concentrations of impurities in the samples were measured by inductively coupled plasma-atomic emission spectrometry (ICP-AES, Optima 2000DV, PerkinElmer Inc., US). Moreover, distributions of the elements in MG-Si before and after alloying with $\mathrm{Cu}$ were studied by an electron probe micro analyzer (EPMA, 
JXA-8100, Japan Electronics Co., Ltd., Japan). Finally, the microstructural evolution in the $\mathrm{Si}-\mathrm{Cu}$ alloy powders after the first step of leaching with $\mathrm{HCl} / \mathrm{HNO}_{3}$ / aqua regia were detected by scanning electron microscopy and energy dispersive spectroscopy (SEM and EDS, SU70, Hitachi Co., Ltd., Japan).

\section{Results and Discussion}

\subsection{The Microstructure of MG-Si before and after Cu Alloying}

According to the research results reported by Santos et al., the composition of the MG-Si used in the acid leaching experiments affects on the extraction of impurities (Santos et al., 1990). Therefore, it is essential to investigate the effect of $\mathrm{Cu}$ alloying on the concentration of $\mathrm{B}$ and $\mathrm{P}$ in MG-Si. The values listed in Table 1 indicated that the initial concentration of $\mathrm{B}$ and $\mathrm{P}$ in raw material was 3.12 and 17.14 ppmw, respectively. After $\mathrm{Cu}$ alloying, the concentration of $\mathrm{B}$ and $\mathrm{P}$ in $\mathrm{Si}$ changed to 2.67 and 12.34 ppmw, respectively. Fig. 2(a) shows the micrograph and EPMA map of the impurity precipitated phase in the used MG-Si. Ca, although a major impurity, was barely detectable, in most cases as small spots. This is because Ca-containing phases are brittle and could be removed during sample preparation. Therefore, $\mathrm{Si}-\mathrm{Fe}$ based phase is the main impurity phase observed in Fig. 2(a). The micro-analysis led to the detection of at least five phases that appeared to have different qualitative composition. It was found that $\mathrm{B}$ and $\mathrm{P}$ did not easily co-precipitate and form compounds owing to their segregation behavior in MG-Si. Fig. 2(b) shows the micrographs and the EPMA map analysis of the $\mathrm{Si}-\mathrm{Cu}$ alloy phase in $\mathrm{Si}-50$ wt.\% $\mathrm{Cu}$ alloy. It is found that the intensities of $\mathrm{B}$ and $\mathrm{P}$ in the alloy phase are higher than those 
in the Si phase. The results indicated that the solidification sequence of the liquid alloy may determine the distribution of $\mathrm{B}$ and $\mathrm{P}$, because liquid $\mathrm{Si}-\mathrm{Cu}$ alloys exhibited higher affinity for $\mathrm{B}$ and $\mathrm{P}$ than the solid $\mathrm{Si}$ phase. This led to a low segregation coefficient of B and P between solid Si phase and liquid alloy leading to effective B and $\mathrm{P}$ getting by $\mathrm{Cu}$-alloying.

\section{Fig. 2}

\subsection{The Acid Sensitivity of Si-Cu Alloy}

The microstructural evolution in the $\mathrm{Si}-\mathrm{Cu}$ alloy powder after the first step of leaching with $\mathrm{HCl} / \mathrm{HNO}_{3} /$ aqua regia is revealed in Fig. 3. Images in Fig. 3(a) show that most of the $\mathrm{Si}-\mathrm{Cu}$ alloy is dissolved in $\mathrm{HCl}$; however, some residues remain attached to the surface of the $\mathrm{Si}$ grains. The residues had high content of $\mathrm{Cu}$ because $\mathrm{Cu}$ could not react with $\mathrm{HCl}$ under the experimental conditions. Fig. 3(b) exhibits that the $\mathrm{Si}-\mathrm{Cu}$ phase (mostly $\mathrm{Cu}_{3} \mathrm{Si}$ ) covers on the $\mathrm{Si}$ grains. Fig. 3(c) shows that $\mathrm{Si}-\mathrm{Cu}$ alloy phase is desquamated from the $\mathrm{Si}$ grain in the forms of $\mathrm{CuCl}$ and $\mathrm{CuCl}_{2}$, which can be removed by the subsequent acid leaching. The reaction that led to the extraction of $\mathrm{Cu}$ from $\mathrm{Si}-\mathrm{Cu}$ alloy by $\mathrm{HNO}_{3}$ and aqua regia can be expressed by equations (1) and (2). To determine the purifying effect of $\mathrm{Cu}$ alloying, the extraction of MG-Si was done via the same acid leaching procedure. The extraction yields of B, $\mathrm{P}$ and metal in MG-Si and $\mathrm{Si}-50$ wt.\% $\mathrm{Cu}$ alloy after leaching with $\mathrm{HCl}, \mathrm{HNO}_{3}$, and aqua regia are shown in Figs. 4 and 5, respectively. For MG-Si, it is confirmed that B and $\mathrm{P}$ removal by acid leaching is attributed to a small amount of $\mathrm{B}$ and $\mathrm{P}$ that is dissolved in the precipitated phase located at the grain boundaries (Meteleva-Fischer 
et al., 2013; Hu et al., 2013). Fig. 4 demonstrates that leaching with aqua regia is found to be more efficient in $\mathrm{B}$ and $\mathrm{P}$ removal than leaching with $\mathrm{HCl}$ and $\mathrm{HNO}_{3}$, up to $21.0 \% \mathrm{~B}$ and $23.2 \% \mathrm{P}$ are leached. For $\mathrm{Si}-50$ wt.\% $\mathrm{Cu}$ alloy, $\mathrm{B}$ and $\mathrm{P}$ easily co-precipitate and form compounds $\left(\mathrm{M}_{\mathrm{x}} \mathrm{B}_{\mathrm{y}}\right.$ or $\mathrm{M}_{\mathrm{x}} \mathrm{P}_{\mathrm{y}} ; \mathrm{M}=$ metal impurity in $\mathrm{Si}-\mathrm{Cu}$ alloy) in the $\mathrm{Si}-\mathrm{Cu}$ alloy phase with the decrease of segregation coefficient, and the extraction of $\mathrm{B}$ and $\mathrm{P}$ by $\mathrm{HCl}, \mathrm{HNO}_{3}$, and aqua regia can be expressed using equations (3)-(8). It was found that the use of aqua regia for leaching provided significantly better results than $\mathrm{HCl}$ and $\mathrm{HNO}_{3}$ (Fig. 5). With aqua regia, the extraction yields of B and $\mathrm{P}$ are $58.7 \%$ and $42.2 \%$, respectively. Moreover, leaching by aqua regia allows for a good separation between the $\mathrm{Si}$ grain and the $\mathrm{Si}-\mathrm{Cu}$ alloy phase. This phenomenon can be explained by examining the leaching mechanism given below:

$3 \mathrm{Cu}(\mathrm{s})+8 \mathrm{HNO}_{3}$ (aq.) $\rightarrow 3 \mathrm{Cu}\left(\mathrm{NO}_{3}\right)_{2}$ (aq.) $+4 \mathrm{H}_{2} \mathrm{O}(\mathrm{l})+2 \mathrm{NO}(\mathrm{g})$

$3 \mathrm{Cu}(\mathrm{s})+2 \mathrm{HNO}_{3}$ (aq.) $+6 \mathrm{HCl} \rightarrow 3 \mathrm{CuCl}_{2}(\mathrm{~s})+4 \mathrm{H}_{2} \mathrm{O}(\mathrm{l})+2 \mathrm{NO}(\mathrm{g})$

$\mathrm{M}_{\mathrm{x}} \mathrm{B}_{\mathrm{y}}(\mathrm{s})+\mathrm{xy} \mathrm{HCl}($ aq. $)+3 \mathrm{y} \mathrm{H}_{2} \mathrm{O}(\mathrm{l}) \rightarrow \mathrm{x} \mathrm{MCl}_{\mathrm{y}}($ aq. $)+\mathrm{y} \mathrm{B}(\mathrm{OH})_{3}$ (aq.) $+(\mathrm{xy}+3 \mathrm{y}) / 2$

$\mathrm{H}_{2}(\mathrm{~g})$

$\mathrm{M}_{\mathrm{x}} \mathrm{P}_{\mathrm{y}}(\mathrm{s})+\mathrm{xy} \mathrm{HCl}$ (aq.) $+4 \mathrm{y} \mathrm{H}_{2} \mathrm{O}(\mathrm{l}) \rightarrow \mathrm{x} \mathrm{MCl}_{\mathrm{y}}$ (aq.) $+\mathrm{y} \mathrm{H}_{3} \mathrm{PO}_{4}$ (aq.) $+(\mathrm{xy}+5 \mathrm{y}) / 2$

$\mathrm{H}_{2}(\mathrm{~g})$

$\mathrm{M}_{\mathrm{x}} \mathrm{B}_{\mathrm{y}}(\mathrm{s})+(4 \mathrm{xy}+3 \mathrm{y}) / 3 \mathrm{HNO}_{3}($ aq. $)+(3 \mathrm{y}-2 \mathrm{xy}) / 3 \mathrm{H}_{2} \mathrm{O}(\mathrm{l}) \rightarrow \mathrm{x} \mathrm{M}\left(\mathrm{NO}_{3}\right)_{\mathrm{y}}($ aq. $)+$ $\mathrm{yB}(\mathrm{OH})_{3}($ aq. $)+(\mathrm{xy}+3 \mathrm{y}) / 3 \mathrm{NO}(\mathrm{g})$

$\mathrm{M}_{\mathrm{x}} \mathrm{P}_{\mathrm{y}}(\mathrm{s})+(4 \mathrm{xy}+5 \mathrm{y}) / 3 \mathrm{HNO}_{3}$ (aq.) $+(2 \mathrm{y}-2 \mathrm{xy}) / 3 \mathrm{H}_{2} \mathrm{O}(\mathrm{l}) \rightarrow \mathrm{x} \mathrm{M}\left(\mathrm{NO}_{3}\right)_{\mathrm{y}}$ (aq.) $+\mathrm{y}$

$\mathrm{H}_{3} \mathrm{PO}_{4}$ (aq.) $+(x y+5 y) / 3 \mathrm{NO}(\mathrm{g})$

$\mathrm{M}_{\mathrm{x}} \mathrm{B}_{\mathrm{y}}(\mathrm{s})+(\mathrm{xy}+3 \mathrm{y}) / 3 \mathrm{HNO}_{3}$ (aq.) $+\mathrm{xy} \mathrm{HCl}(\mathrm{aq})+.(\mathrm{y}-2 / 3 \mathrm{xy}) \mathrm{H}_{2} \mathrm{O}(\mathrm{l}) \rightarrow \mathrm{x} \mathrm{MCl}_{\mathrm{y}}(\mathrm{aq}$. 
$+\mathrm{y} \mathrm{B}(\mathrm{OH})_{3}(\mathrm{aq})+.(\mathrm{xy}+3 \mathrm{y}) / 3 \mathrm{NO}(\mathrm{g})$

$\mathrm{M}_{\mathrm{x}} \mathrm{B}_{\mathrm{y}}(\mathrm{s})+(\mathrm{xy}+5 \mathrm{y}) / 3 \mathrm{HNO}_{3}$ (aq.) $+\mathrm{xy} \mathrm{HCl}($ aq. $)+(2 \mathrm{y}-2 \mathrm{xy}) / 3 \mathrm{H}_{2} \mathrm{O}(\mathrm{l}) \rightarrow \mathrm{x} \mathrm{MCl}$ (aq.)

$+\mathrm{y} \mathrm{H}_{3} \mathrm{PO}_{4}$ (aq.) $+(\mathrm{xy}+5 \mathrm{y}) / 3 \mathrm{NO}(\mathrm{g})$

$\mathrm{Cu}_{3} \mathrm{Si}$ cannot be removed completely by $\mathrm{HCl}, \mathrm{HNO}_{3}$, or aqua regia; therefore, a second step is applied. It is known that $\mathrm{HNO}_{3}$ is a strong oxidant and that $\mathrm{HF}$ is a weak acid; however, $\mathrm{F}^{-}$is a strong complexing agent (Sun et al., 2013). In the leaching procedure, $\mathrm{Cu}_{3} \mathrm{Si}$ gets oxidized to $\mathrm{H}_{2} \mathrm{SiF}_{6}$, and the unstable $\mathrm{H}_{2} \mathrm{SiF}_{6}$ decomposes to generate $\mathrm{SiF}_{4}$ gas and $\mathrm{HF}$. Exothermic dissolution of $\mathrm{Cu}_{3} \mathrm{Si}$ into $\mathrm{HNO}_{3}+\mathrm{HF}$ mixed acid results in intense bubbling owing to the formation of $\mathrm{SiF}_{4}$ and nitrogen oxide gases, further the small-size particles rise to the top of the container, and then spill out. Therefore, a small amount of ethanol was added to the solution to control this leaching procedure. The reactions that take place during the second step of acid

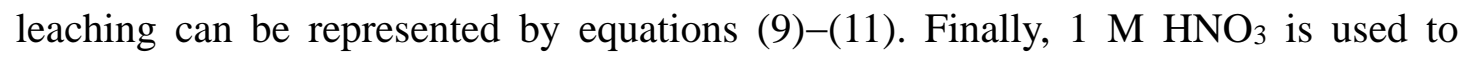
desorb $\mathrm{SiF}_{4}$ and nitrogen oxide gases from the surface of particles during the third leaching step.

$\mathrm{Cu}_{3} \mathrm{Si}$ (s) $+16 \mathrm{HNO}_{3}$ (aq.) $+6 \mathrm{HF}$ (aq.) $\rightarrow 3 \mathrm{Cu}\left(\mathrm{NO}_{3}\right)_{2}$ (aq.) $+\mathrm{H}_{2} \mathrm{SiF}_{6}$ (aq.) $+10 \mathrm{H}_{2} \mathrm{O}$ (l)

$+10 \mathrm{NO}_{2}(\mathrm{~g})$

$3 \mathrm{Cu}_{3} \mathrm{Si}(\mathrm{s})+28 \mathrm{HNO}_{3}$ (aq.) $+18 \mathrm{HF}$ (aq.) $\rightarrow 9 \mathrm{Cu}\left(\mathrm{NO}_{3}\right)_{2}$ (aq.) $+3 \mathrm{H}_{2} \mathrm{SiF}_{6}$ (aq.) +

$20 \mathrm{H}_{2} \mathrm{O}(\mathrm{l})+10 \mathrm{NO}(\mathrm{g})$

$4 \mathrm{Cu}_{3} \mathrm{Si}$ (s) $+34 \mathrm{HNO}_{3}$ (aq.) $+24 \mathrm{HF}$ (aq.) $\rightarrow 12 \mathrm{Cu}\left(\mathrm{NO}_{3}\right)_{2}$ (aq.) $+4 \mathrm{H}_{2} \mathrm{SiF}_{6}$ (aq.) +

$25 \mathrm{H}_{2} \mathrm{O}(\mathrm{l})+5 \mathrm{~N}_{2} \mathrm{O}(\mathrm{g})$

Our studies demonstrated that this extraction of $\mathrm{B}$ and $\mathrm{P}$ was feasible due to the 
unique microstructure of the $\mathrm{Si}-\mathrm{Cu}$ alloy and the effective acid leaching procedure.

Fig. 3

Fig. 4

Fig. 5

\subsection{Statistical Analysis: Effects of Testing Parameters on the Leaching Process}

A series of systematic leaching trials were performed in order to study the effects of particle size, time, and temperature on the degree of purification of the $\mathrm{Si}-50 \mathrm{wt} . \%$ $\mathrm{Cu}$ alloy. The following results illustrated the main effects of each of these parameters.

\subsubsection{Effect of Particle Size}

In this step, five batches of the $\mathrm{Si}-\mathrm{Cu}$ alloy with different particle size ranges were first treated with $2 \mathrm{M}$ aqua regia at $70{ }^{\circ} \mathrm{C}$ for $5 \mathrm{~h}$ with a liquid / solid ratio of 10:1. Then, these particles were treated with $2 \mathrm{M} \mathrm{HNO}_{3}+$ trace $\mathrm{HF}$ and then with $1 \mathrm{M}$ $\mathrm{HNO}_{3}$. The graph of percentage extraction vs. particle size for $\mathrm{B}$ and $\mathrm{P}$ is shown in Fig. 6. Over $57.5 \% \mathrm{~B}$ and $34.9 \% \mathrm{P}$ were leached when the particle size range was 74 $106 \mu \mathrm{m}$. Further increase in the particle size caused significant decrease in the yield of B and P. Thus, 74-106 $\mu \mathrm{m}$ was selected as the optimum particle size range.

For MG-Si, research results indicated that more friable phases containing impurities were concentrated in the finer fraction of particles during sieving. It is found that these could not be so easily removed by acid leaching (Zhang et al., 2013). In general, the purification yield is similar for most elements with the exception of elements with a low segregation coefficient such as B and P (Santos et al., 1990). In 
this study, $\mathrm{Cu}$, as the $\mathrm{B}$ and $\mathrm{P}$ getter, changed the distribution and state of $\mathrm{B}$ and $\mathrm{P}$. The results showed that better leaching efficiencies were obtained with batches with particle size of $74-106 \mu \mathrm{m}$ than with batches with smaller average particle sizes. In the study of Margarido et al., it was found that appropriate particle size was needed to facilitate the elimination of impurities phases for its attack by acid leaching (Margarido et al., 1997). This demonstrated that grinding to a very fine particle size was not required to obtain high purity $\mathrm{Si}$. Consequently, this particle size effect led to the concentration of difficult-to-remove impurity phases in the finer fractions during the grinding and sieving processes. Another contributing factor was the large surface of the grain capable of absorbing a large amount of $\mathrm{SiF}_{4}$ and nitrogen oxide gases. The surface could not desorb these gases before the occurrence of acid leaching. Therefore, the acid leaching reactions with $\mathrm{B}$ and $\mathrm{P}$ were restricted in the smaller particles sizes $(0-74 \mu \mathrm{m})$ even though more grain boundary was exposed.

\section{Fig. 6}

\subsubsection{Effect of Leaching Time}

A set of tests with different leaching times from 1 to $5 \mathrm{~h}$ with $1 \mathrm{~h}$ interval was performed whilst keeping the temperature and other leaching conditions constant. The plot of percentage extraction yields of $\mathrm{B}$ and $\mathrm{P}$ vs. leaching times is shown in Fig. 7. The percentage extraction yield of $\mathrm{B}$ and $\mathrm{P}$ increases sharply in the initial stage of leaching. This is attributed to the rapid reaction between the $\mathrm{Si}-\mathrm{Cu}$ alloy and aqua regia. Subsequently, the extraction yield rate of $\mathrm{B}$ and $\mathrm{P}$ decreases as the leaching process continues. The results indicate that a leaching time of $5 \mathrm{~h}$ is sufficient to leach 
over $58.4 \% \mathrm{~B}$ and $42.4 \% \mathrm{P}$.

Fig. 7

\subsubsection{Effect of Temperature}

The effect of temperature on the extraction yield of B and $\mathrm{P}$ was investigated by conducting tests in the range 30 to $70{ }^{\circ} \mathrm{C}$, keeping the remaining leaching conditions constant. The results are presented in Fig. 8. The extraction yield of B and P increases with increasing temperature and a maximum removal of $51.7 \% \mathrm{~B}$ and $39.6 \% \mathrm{P}$ are obtained at $70^{\circ} \mathrm{C}$

\section{Fig. 8}

\subsection{Cracking of Si-Cu Alloy during Leaching in Aqua Regia}

\subsubsection{Chemical Cracking Process}

The morphology of the $\mathrm{Si}-\mathrm{Cu}$ alloy briquette before and after leaching in aqua regia is shown in Fig. 9 demonstrating the cracking of the bulk $\mathrm{Si}-\mathrm{Cu}$ alloy and the dissolution of $\mathrm{Si}-\mathrm{Cu}$ alloy phase during the leaching process. A similar phenomenon has been reported in 1993, wherein, acid leaching was introduced to separate solvent metal from Si-Fe alloy (Margarido et al., 1993). They also developed a cracking shrinking model to describe the non-catalytic solid-fluid reactions when particles crack during the process (Martins and Margarido, 1996). Moreover, the cracking shrinking model was used to illustrate the leaching process of slag treated MG-Si (Fang et al., 2014). Based on the results of the researches conducted by Margarido et al. and Fang et al., a modified cracking shrinking model was applied to analyze the results of our study. The acid leaching mechanism using the modified cracking 
shrinking model is shown in Fig. 9.

\section{Fig. 9}

\subsubsection{Kinetics Analysis}

In the modified cracking shrinking model, the leaching process is controlled by chemical reaction at the particle surface, or diffusion through the product layer (Levenspiel, 1999) or a combination of both. The kinetic calculations are given by the following equations (12) and (13):

For chemical reaction control, $K_{1} t=1-(1-x)^{\frac{1}{3}}$

For product layer diffusion control, $K_{2} t=1-\frac{2}{3} x-(1-x)^{\frac{2}{3}}$

Moreover, assuming that both the interfacial transfer and diffusion across the product layer affect the reaction rate, the following expression can be used to describe the process (Dickinson and Heal, 1999):

$$
K_{3} t=\frac{1}{3} \ln (1-x)+\left[(1-x)^{-\frac{1}{3}}-1\right]
$$

where, $\mathrm{K}$ is the reaction rate constant, $\mathrm{t}$ is the reaction time, and $x$ is the reacted fraction of impurity. The extraction of $\mathrm{B}$ and $\mathrm{P}$ at $70{ }^{\circ} \mathrm{C}$ was better than at other temperatures; therefore, the temperature of modeling calculation was selected as 70 ${ }^{\circ} \mathrm{C}$. According to equations $(12)-(14)$, a plot of $\left[1-(1-x)^{\frac{1}{3}}\right]$ vs. time is a straight line with a slope $\mathrm{K}_{1}$ when the chemical reaction is the rate controlling step. Similarly, when the leaching process is controlled by diffusion through the product layer, a plot of $\left[1-\frac{2}{3} x-(1-x)^{\frac{2}{3}}\right]$ vs. time is a straight line with a slope $K_{2}$. If both the interfacial transfer and diffusion across the product layer affect the reaction rate, a plot of $\left[\frac{1}{3} \ln (1-x)+(1-x)^{-\frac{1}{3}}-1\right]$ vs. time is also a straight line with a slope $\mathrm{K}_{3}$. 
Fig. 10 shows the linear fitting of the extraction yields of $\mathrm{B}$ and $\mathrm{P}$ when equations (12)-(14) are applied. The rate constants and correlation coefficient values of these kinetic equations are listed in Table 2. Applying the model to fit these experimental data, it was found that the optimized linear fittings were obtained when equation (14) was applied. The correlation coefficients of $\mathrm{B}$ and $\mathrm{P}$ were 0.9844 and 0.9665 , respectively. These results demonstrated that the leaching kinetics of $\mathrm{B}$ and $\mathrm{P}$ were controlled by both interfacial transfer and diffusion across the product layer taking place during the leaching process. In the second leaching step $\left(\mathrm{HNO}_{3}+\mathrm{HF}\right)$, the cracking shrinking mechanism was no more valid because the solid was already cracked during the first step (aqua regia).

Fig. 10

Table 2

\section{Conclusion}

In this study, MG-Si was purified by a combination of $\mathrm{Cu}$-alloying and aqua regia leaching. The behavior of $\mathrm{B}$ and $\mathrm{P}$ in MG-Si after $\mathrm{Cu}$-alloying was studied. It was found that upon the addition of $\mathrm{Cu}$, the segregation coefficients of $\mathrm{B}$ and $\mathrm{P}$ between solid Si phase and liquid alloy were lowered. The $\mathrm{Si}-\mathrm{Cu}$ alloy behaved as the $\mathrm{B}$ and $\mathrm{P}$ getter in this system. Moreover, the leaching results showed that the total extraction yields of $\mathrm{B}$ and $\mathrm{P}$ were 58.7 and $42.2 \%$, respectively, by the combination process. The formation of compounds between $\mathrm{B} / \mathrm{P}$ and $\mathrm{Si}-\mathrm{Cu}$ alloy during the $\mathrm{Cu}$-alloying process was also found to be an important part of B and P removal. It was found that aqua regia provided a better extraction yield of $\mathrm{B}$ and $\mathrm{P}$ compared to $\mathrm{HCl}$ and $\mathrm{HNO}_{3}$, 
and was better at differentiating between the Si grain and the alloy phase. Furthermore, the extraction yield of $\mathrm{B}$ and $\mathrm{P}$ increased with increasing leaching temperature and time. The best particle size range for acid leaching was found to be $74-106 \mu \mathrm{m}$. A modified cracking shrinking model was applied to demonstrate that the aqua regia leaching kinetics of $\mathrm{B}$ and $\mathrm{P}$ were controlled by both interfacial transfer and diffusion through the product layer during leaching.

\section{Acknowledgements}

We gratefully acknowledge the support of the National Science Foundation of China-Yunnan (U1137601), the National Natural Science Foundation of China (Nos.51334004 and 51204143), and the Scientific and Technological Innovation Platform of Fujian Province (2006L2003). 


\section{References}

Braga, A.F.B., Moreira, S.P., Zampieri, P.R., Bacchin, J.M.G. and Mei, P.R., 2008. New processes for the production of solar-grade polycrystalline silicon: A review. Solar Energy Materials and Solar Cells, 92(4), 418-424.

Lee, J. K., Lee, J.S., Jang, B.Y., Kim, J.S., Ahn, Y.S., Kang, G.H., Song, H.E., Kang, M.G. and Cho, C.H., 2015. 6" crystalline silicon solar cell with electron-beam melting-based metallurgical route. Solar Energy, 115, 322-328.

Mukashev, B.N., Abdullin, K.A., Tamendarov, M.F., Turmagambetov, T.S., Beketov, B.A., Page, M.R. and Kline, D.M., 2009. A metallurgical route to produce upgraded silicon and monosilane. Solar Energy Materials \& Solar Cells,93(10), 1785-1791.

Sakata, T., Miki, T. and Morita, K., 2002. Removal of iron and titanium in poly-crystalline silicon by acid leaching. Journal-Japan Institute of Metal, 66(5), 459-465.

Yoshikawa, T. and Morita, K., 2012. An evolving method for solar-grade silicon production: solvent refining. Jom, 64(8), 946-951.

Zheng, S. S., Abel Engh, T., Tangstad, M. and Luo, X. T., 2011. Separation of phosphorus from silicon by induction vacuum refining. Separation and Purification Technology, 82, 128-137.

Jung, E.J., Moon, B.M., Seok, S.H. and Min, D.J., 2014. The mechanism of boron removal in the $\mathrm{CaO}-\mathrm{SiO}_{2}-\mathrm{Al}_{2} \mathrm{O}_{3}$ slag system for SoG-Si. Energy, 66, 35-40.

Tan, Y., Ren, S.Q., Shi, S., Wen, S.T., Jiang, D.C., Dong, W., Ji, M. and Sun, S.H., 2014. Removal of aluminum and calcium in multicrystalline silicon by vacuum induction melting and directional solidification. Vacuum, 99, 272-276.

Jiang, D.C., Ren, S.Q., Shi, S., Dong, W., Qiu, J.S., Tan, Y. and Li, J.Y., 2014. Phosphorus removal from silicon by vacuum refining and directional solidification. Journal of Electronic Materials, 43(2), 314-319.

Sim, B.C., Kim, K.H. and Lee, H.W., 2006. Boron segregation control in silicon crystal ingots grown in Czochralski process. Journal of Crystal Growth, 290(2), 665-669.

Hu, L., Wang, Z., Gong, X., Guo, Z. and Zhang, H.,2013. Impurities Removal from metallurgical grade silicon by combined $\mathrm{Sn}-\mathrm{Si}$ and $\mathrm{Al}-\mathrm{Si}$ refining processes. Metallurgical and Materials Transactions B,44(4), 828-836.

Li, Y.Q., Tan, Y., Li, J.Y., Xu, Q. and Liu, Y., 2014. Effect of Sn content on microstructure and boron distribution in Si-Al alloy. Journal of Alloys and Compounds, 583, 85-90.

Ma, X.D., Yoshikawa, T. and Morita, K., 2013. Si growth by directional solidification of Si-Sn alloys to produce solar-grade Si. Journal of Crystal Growth, 377, 192-196.

Olesinski, R. and Abbaschian, G., 1986. The Cu-Si (copper-silicon) system. Bulletin of Alloy Phase Diagrams, 7(2), 170-178.

Mitrasinovic, A.M. and Utigard, T.A., 2009. Refining Silicon for Solar Cell Application by Copper Alloying. Silicon, 1(4), 239-248.

Yoshikawa, T. and Morita, K., 2005. Refing of $\mathrm{Si}$ by the solidification of Si-Al melt with electromagnetic force. ISIJ International, 45(7), 967-971.

Shimpo, T., Yoshikawa, T. and Morita, K., 2004. Thermodynamic study of the effect of calcium on removal of phosphorus from silicon by acid leaching treatment. Metallurgical and Materials Transactions B, 35(2), 277-284.

Yoshikawa, T., Arimura, K. and Morita, K., 2005. Boron removal by titanium addition in solidification 
refining of silicon with Si-Al melt. Metallurgical and Materials Transactions B, 36(6), 837-842.

Johnston, M.D. and Barati, M., 2013. Calcium and titanium as impurity getter metals in purification of silicon. Separation and Purification Technology, 107, 129-134.

Visnovec, K., Variawa, C., Utigard, T. and Mitrasinovic, A., 2012. Elimination of impurities from the surface of silicon using hydrochloric and nitric acid. Materials Science in Semiconductor Processing, 16(1), 106-110.

Santos, I.C., Goncalves, A.P., Santos, C.S., Almeida, M, Afonso, M.H. and Cruz, M.J., 1990. Purification of metallurgical grade silicon by acid leaching. Hydrometallurgy, 23(2-3), 237-246.

Meteleva-Fischer Y V, Yang Y, Boom R, Kraaijveld B and Kuntzel H., 2013. Microstructure of metallurgical grade silicon and its acid leaching behaviour by alloying with calcium. Mineral Processing and Extractive Metallurgy, 122(4), 229-237.

Hu, L., Wang, Z., Gong, X.Z., Guo, Z.C. and Zhang, H., 2013. Purification of metallurgical-grade silicon by $\mathrm{Sn}-\mathrm{Si}$ refining system with calcium addition. Separation and Purification Technology, 118, 699-703.

Sun, Y.H., Ye, Q.H., Guo, C.J., Chen, H.Y., Lang, X., David, F., Luo, Q.W. and Yang, C.M., 2013. Purification of metallurgical grade silicon via acid leaching, calcination and quenching before boron complexation. Hydrometallurgy, 139, 64-72.

Zhang, H., Wang, Z., Ma, W.H., Xie, K.Q. and Hu, L., 2013. Chemical cracking effect of aqua regia on the purification of metallurgical-grade silicon. Industrial \& Engineering Chemistry Research, 52(22), 7289-7296.

Margarido, F., Figueiredo, M.O., Queiroz, A. M. and Martins, J. P., 1997. Acid leaching of alloys within the quaternary system Fe-Si-Ca-Al. Industrial \& Engineering Chemistry Research, 36(12), 5291-5295.

Margarido, F., Martins, J.P., Figueiredo, M.O. and Bastos, M.H., 1993. Kinetics of acid leaching refining of an industrial Fe-Si alloy. Hydrometallurgy, 34(1), 1-11.

Martins, J.P. and Margarido, F., 1996. The cracking shrinking model for solid-fluid reactions. Materials Chemistry and Physics, 44(2), 156-169.

Fang, M., Lu, C.H., Huang, L.Q., Lai, H.X., Chen, J., Li, J.T., Ma, W.H., Xing, P.F. and Luo, X.T., 2014. Separation of metal impurities from metallurgical grade silicon via $\mathrm{CaO}-\mathrm{SiO}_{2}-\mathrm{CaF}_{2}$ slag treatment followed by leaching with hydrochloric acid. Separation Science and Technology, 49(14): 2261-2270.

Levenspiel O., 1999. Chemical reaction engineering. Industrial \& engineering chemistry research, 38(11), 4140-4143.

Dickinson, C.F. and Heal, G.R.,1999. Solid-liquid diffusion controlled rate equations. Thermochimica Acta, 340, 89-103. 
Table 1. Impurity concentrations (ppmw) in the raw materials used in the study

\begin{tabular}{ccccccccc}
\hline Sample & $\mathbf{B}$ & $\mathbf{P}$ & $\mathbf{F e}$ & $\mathbf{A l}$ & $\mathbf{C a}$ & $\mathbf{T i}$ & $\mathbf{M n}$ & $\mathbf{N i}$ \\
\hline $\mathrm{MG}-\mathrm{Si}$ & 3.12 & 17.14 & 10.74 & 100.76 & 29.89 & 88.14 & 5.704 & 14.86 \\
$\mathrm{Cu}$ & 2.14 & 8.93 & 13.94 & 19.01 & 1014.11 & 11.17 & 1.04 & 2.96 \\
$\mathrm{Si}-50 \mathrm{wt} \% \mathrm{Cu}$ & 2.67 & 12.34 & 10.83 & 113.14 & 258.13 & 45.776 & 4.919 & 6.282 \\
\hline
\end{tabular}


Table 2. Values of $\mathrm{K}$ and correlation coefficients of $\mathrm{B}$ and $\mathrm{P}$ at $70{ }^{\circ} \mathrm{C}$

\begin{tabular}{ccccccc}
\hline \multirow{2}{*}{ Elements } & \multicolumn{2}{c}{ Rate constants $\left(\mathbf{1 0}^{-\mathbf{3}} \mathbf{h}^{-\mathbf{1}}\right)$} & \multicolumn{3}{c}{ Correlation coefficients } \\
\cline { 2 - 7 } & $\mathrm{K}_{1}$ & $\mathrm{~K}_{2}$ & $\mathrm{~K}_{3}$ & $R_{1}^{2}$ & $R_{2}^{2}$ & $R_{3}^{2}$ \\
\hline $\mathrm{B}$ & 49.6 & 11.2 & 9.9 & 0.9271 & 0.9834 & 0.9844 \\
$\mathrm{P}$ & 31.5 & 5.0 & 3.6 & 0.8690 & 0.9545 & 0.9665 \\
\hline
\end{tabular}




\section{Figure captions}

Fig. 1. Schematic purification process of (a) MG-Si alloyed with $\mathrm{Cu}$ and (b) acid leaching and flow chart of the experimental process.

Fig. 2. The distribution characteristic and composition of the typical impurity phase in (a) MG-Si and (b) Si-50 wt.\% Cu alloy.

Fig. 3. Microstructure and EDS analysis of the $\mathrm{Si}-50 \mathrm{wt} . \% \mathrm{Cu}$ alloy after leaching with (a) $\mathrm{HCl}$, (b) $\mathrm{HNO}_{3}$, and (c) aqua regia. Temperature: $70{ }^{\circ} \mathrm{C}$; initial acid concentration: $2 \mathrm{M}$; time: $5 \mathrm{~h}$; stirring speed: $200 \mathrm{rpm}$.

Fig. 4. The extraction of $\mathrm{B}, \mathrm{P}$, and metals in $\mathrm{MG}-\mathrm{Si}$ after leaching with $\mathrm{HCl}, \mathrm{HNO}_{3}$, and aqua regia. Temperature: $70{ }^{\circ} \mathrm{C}$; initial acid concentration: $2 \mathrm{M}$; time: $5 \mathrm{~h}$; stirring speed: $200 \mathrm{rpm}$.

Fig. 5. The extraction of $\mathrm{B}, \mathrm{P}$, and metals in $\mathrm{Si}-50 \mathrm{wt} . \% \mathrm{Cu}$ alloy after leaching with $\mathrm{HCl}, \mathrm{HNO}_{3}$, and aqua regia. Temperature: $70{ }^{\circ} \mathrm{C}$; initial acid concentration: $2 \mathrm{M}$; time: $5 \mathrm{~h}$; stirring speed: $200 \mathrm{rpm}$.

Fig. 6. Effect of the $\mathrm{Si}-50 \mathrm{wt} . \% \mathrm{Cu}$ alloy particle size on the extraction yield of $\mathrm{B}$ and P. Temperature: $70{ }^{\circ} \mathrm{C}$; initial acid concentration: $2 \mathrm{M}$; time: $5 \mathrm{~h}$; stirring speed: 200 rpm.

Fig. 7. Effect of the leaching time of $\mathrm{Si}-50 \mathrm{wt} . \% \mathrm{Cu}$ alloy on the extraction of $\mathrm{B}$ and $\mathrm{P}$. Particle size: $74-106 \mu \mathrm{m}$; temperature: $70{ }^{\circ} \mathrm{C}$; initial acid concentration: $2 \mathrm{M}$; stirring speed: $200 \mathrm{rpm}$.

Fig. 8. Effect of the leaching temperature of $\mathrm{Si}-50 \mathrm{wt} . \% \mathrm{Cu}$ alloy on the extraction yield of B and P. Particle size: 74-106 $\mu \mathrm{m}$; initial acid concentration: $2 \mathrm{M}$; time: 5 h; stirring speed: $200 \mathrm{rpm}$.

Fig. 9. Schematic illustration of the different stages in the leaching process of the $\mathrm{Si}-50 \mathrm{wt} . \% \mathrm{Cu}$ alloy according to the modified cracking shrinking model.

Fig. 10. Application of the modified shrinking model in the acid leaching of Si-50 wt.\% Cu alloy: (a) B and (b) P. 
(a)

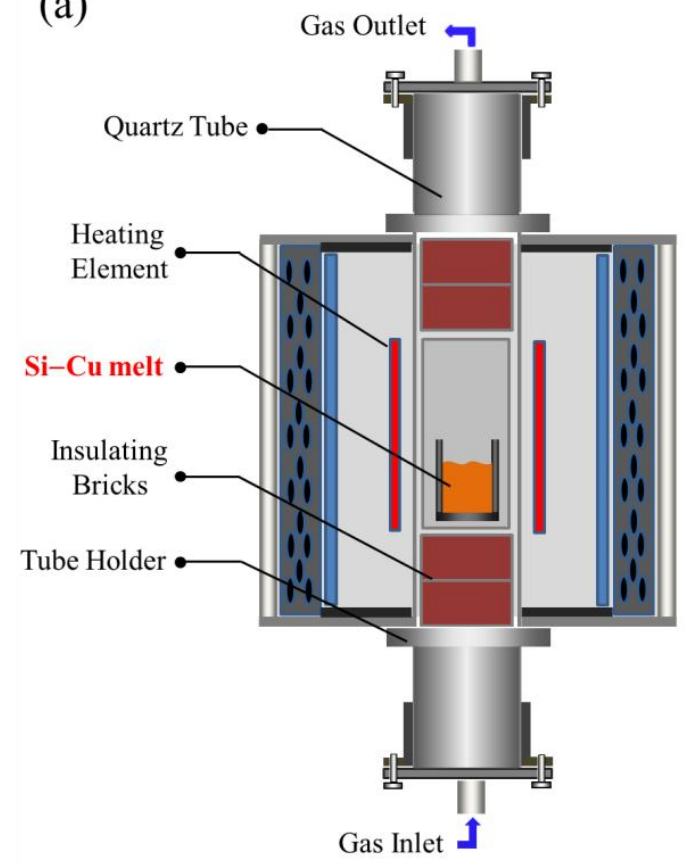

(b)

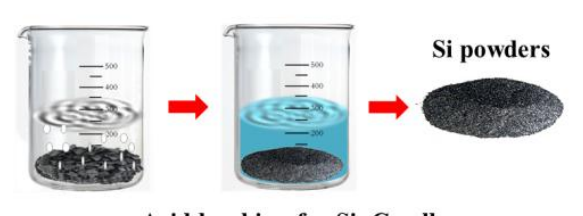

Acid leaching for $\mathrm{Si}-\mathrm{Cu}$ alloy

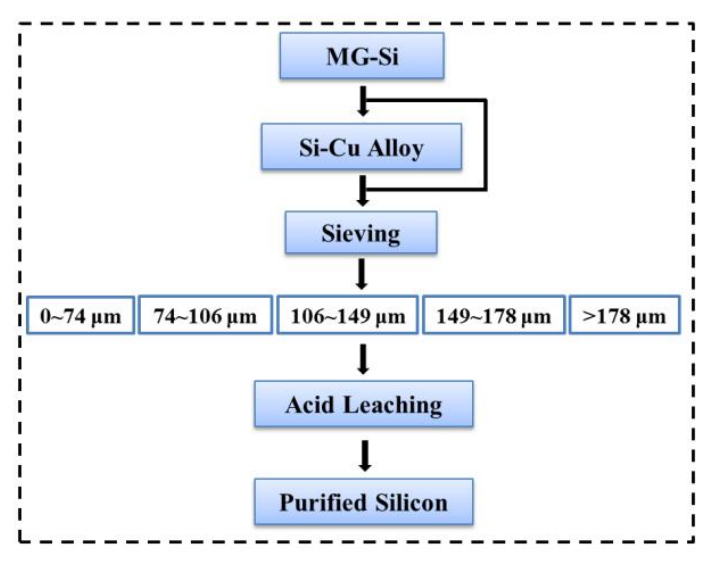

Fig. 1. Schematic purification process of (a) MG-Si alloyed with $\mathrm{Cu}$ and (b) acid leaching and flow chart of the experimental process. 

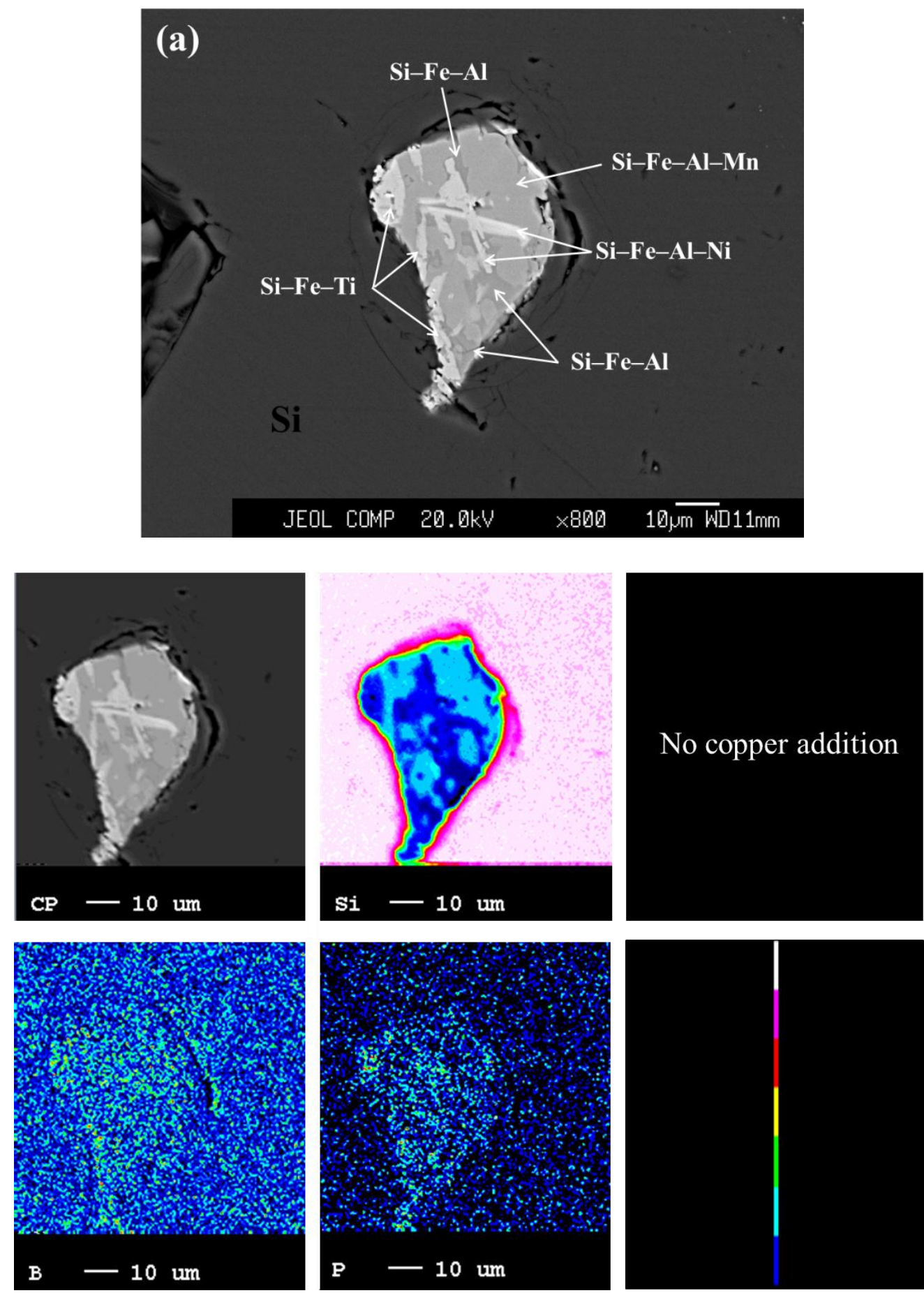

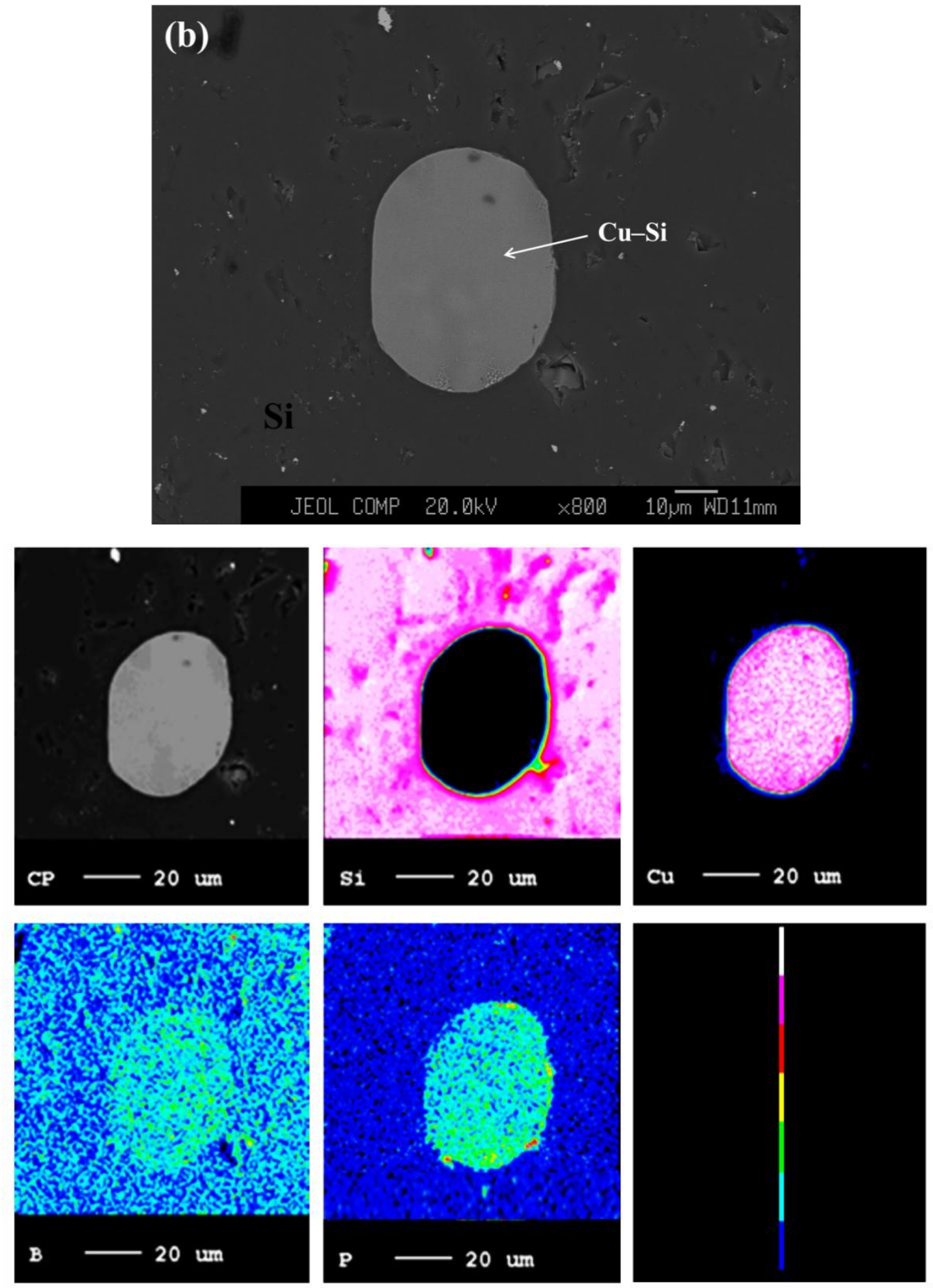

Fig. 2. The distribution characteristic and composition of the typical impurity phase in

(a) MG-Si and (b) Si-50 wt.\% Cu alloy. 

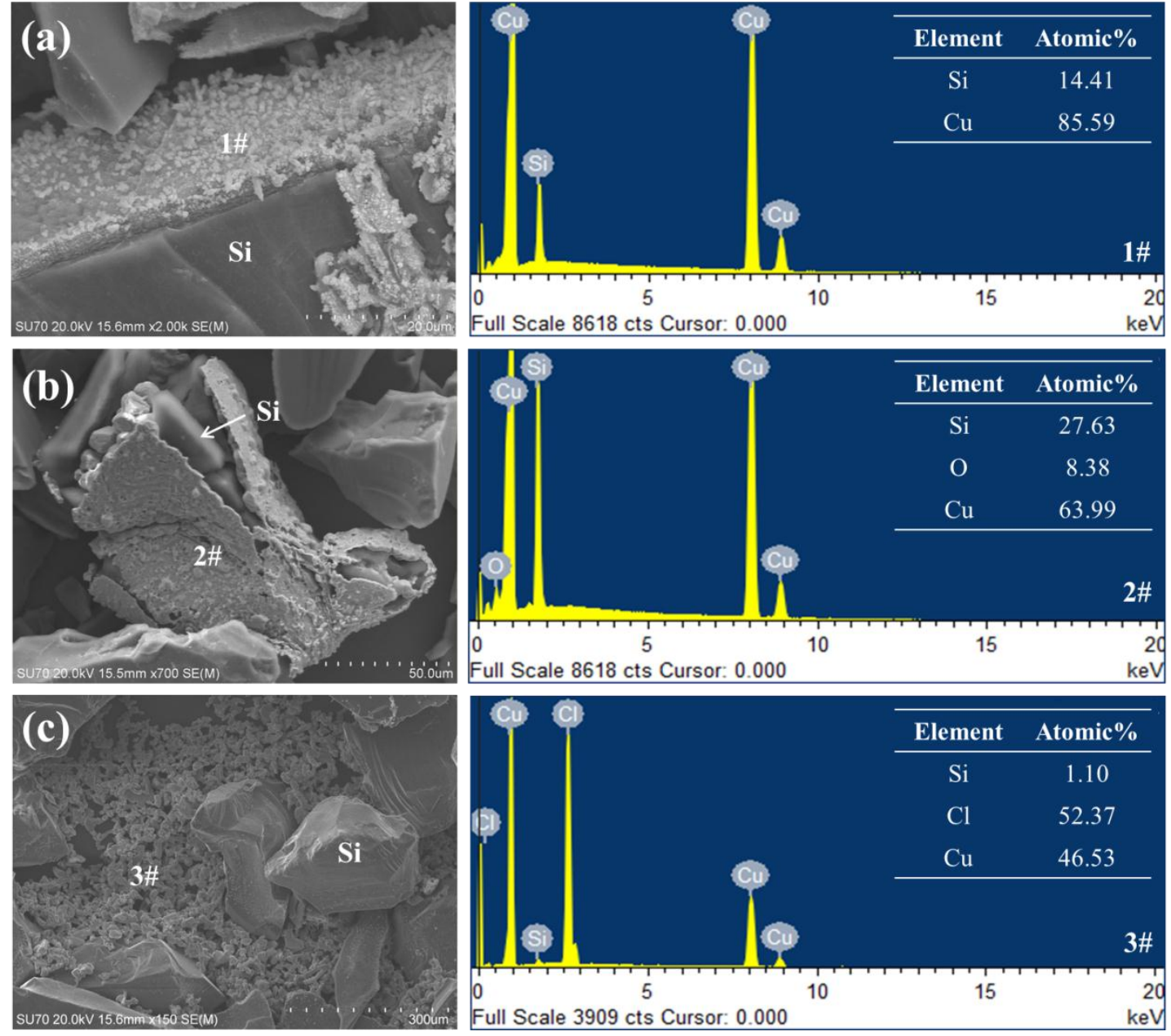

Fig. 3. Microstructure and EDS analysis of the $\mathrm{Si}-50 \mathrm{wt} . \% \mathrm{Cu}$ alloy after leaching with (a) $\mathrm{HCl}$, (b) $\mathrm{HNO}_{3}$, and (c) aqua regia. Temperature: $70{ }^{\circ} \mathrm{C}$; initial acid concentration: $2 \mathrm{M}$; time: $5 \mathrm{~h}$; stirring speed: $200 \mathrm{rpm}$. 


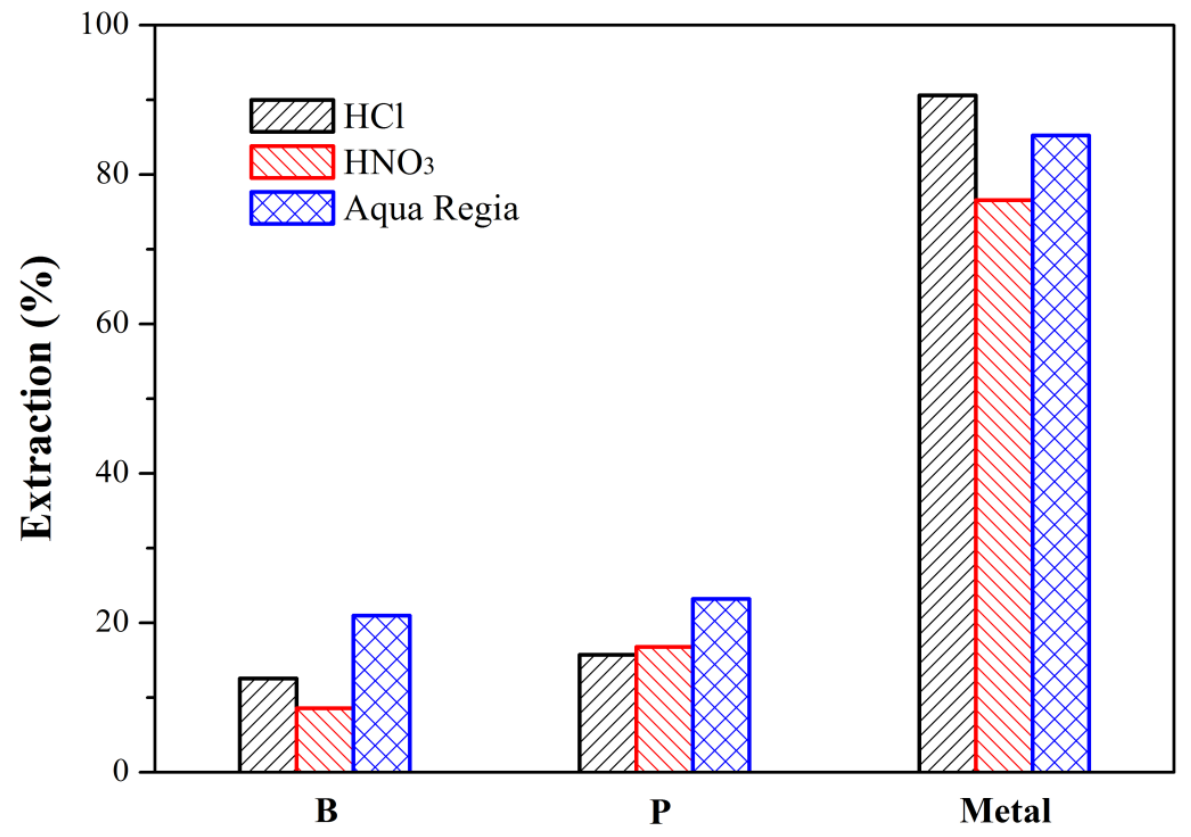

Fig. 4. The extraction of $\mathrm{B}, \mathrm{P}$, and metals in $\mathrm{MG}-\mathrm{Si}$ after leaching with $\mathrm{HCl}, \mathrm{HNO}_{3}$, and aqua regia. Temperature: $70^{\circ} \mathrm{C}$; initial acid concentration: $2 \mathrm{M}$; time: $5 \mathrm{~h}$; stirring speed: $200 \mathrm{rpm}$. 


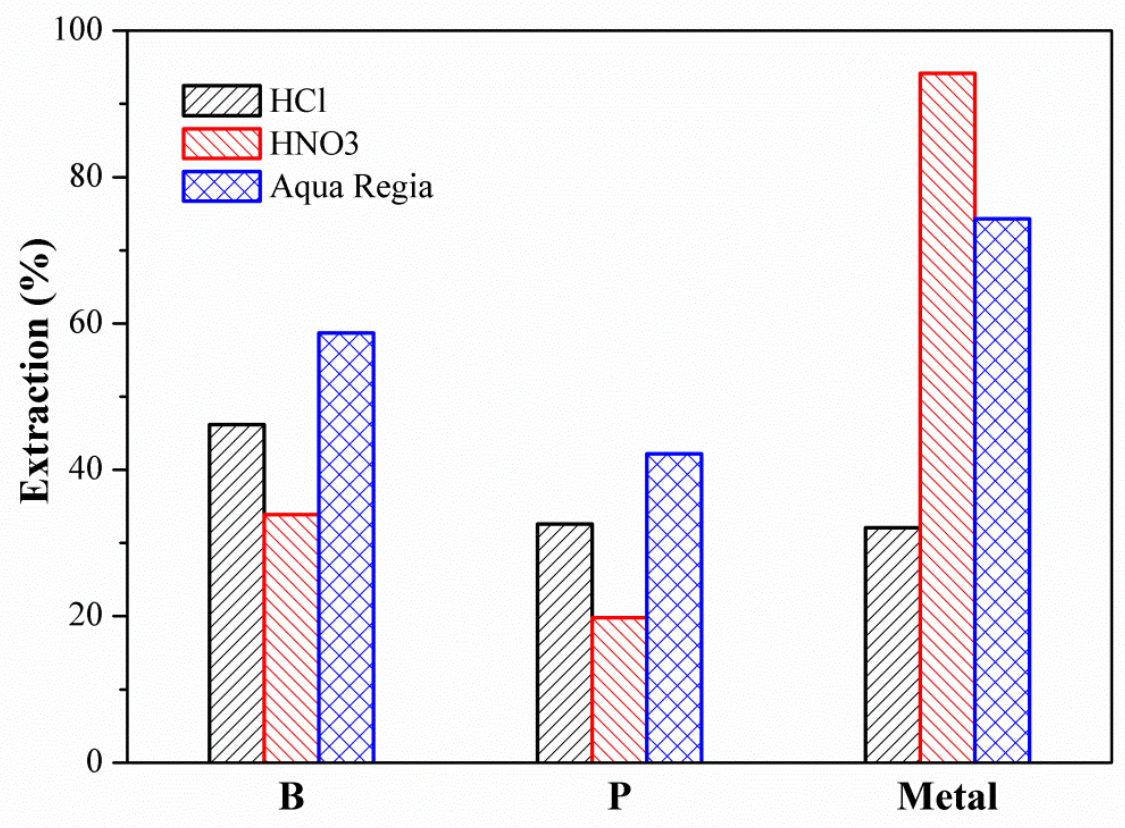

Fig. 5. The extraction of $\mathrm{B}, \mathrm{P}$, and metals in $\mathrm{Si}-50 \mathrm{wt} . \% \mathrm{Cu}$ alloy after leaching with $\mathrm{HCl}, \mathrm{HNO}_{3}$, and aqua regia. Particle size: $74-106 \mu \mathrm{m}$; Temperature: $70{ }^{\circ} \mathrm{C}$; initial acid concentration: $2 \mathrm{M}$; time: $5 \mathrm{~h}$; stirring speed: $200 \mathrm{rpm}$. 


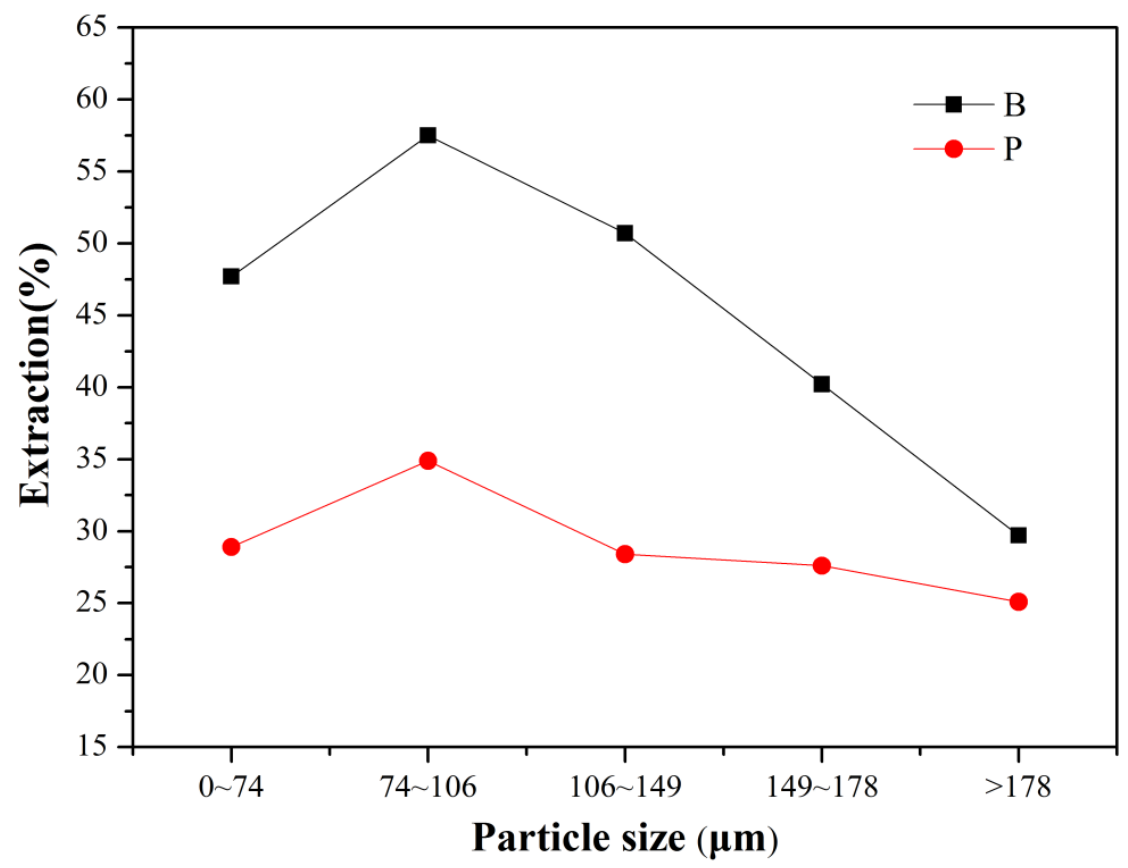

Fig. 6. Effect of the Si-50 wt.\% Cu alloy particle size on the extraction yield of B and P. Temperature: $70{ }^{\circ} \mathrm{C}$; initial acid concentration: $2 \mathrm{M}$; time: $5 \mathrm{~h}$; stirring speed: 200 rpm. 


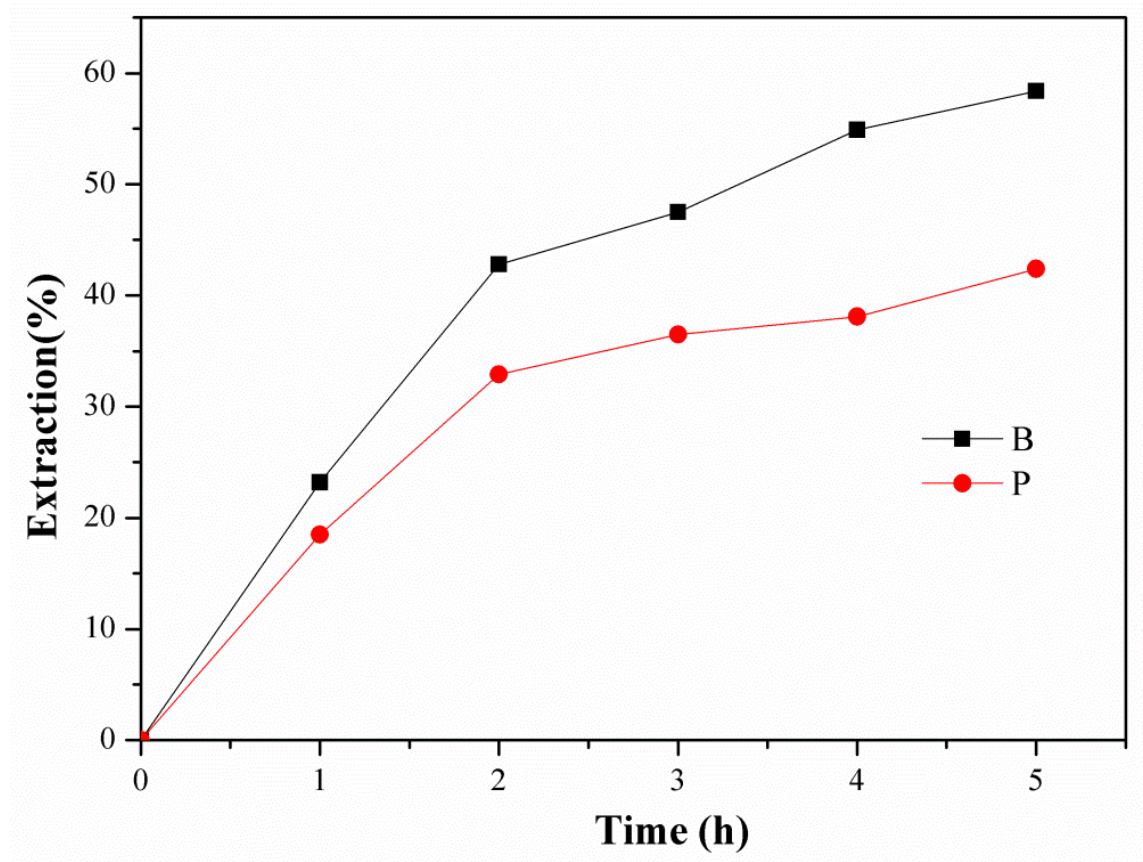

Fig. 7. Effect of the leaching time of $\mathrm{Si}-50 \mathrm{wt} . \% \mathrm{Cu}$ alloy on the extraction of $\mathrm{B}$ and $\mathrm{P}$. Particle size: $74-106 \mu \mathrm{m}$; temperature: $70{ }^{\circ} \mathrm{C}$; initial acid concentration: $2 \mathrm{M}$; stirring speed: $200 \mathrm{rpm}$. 


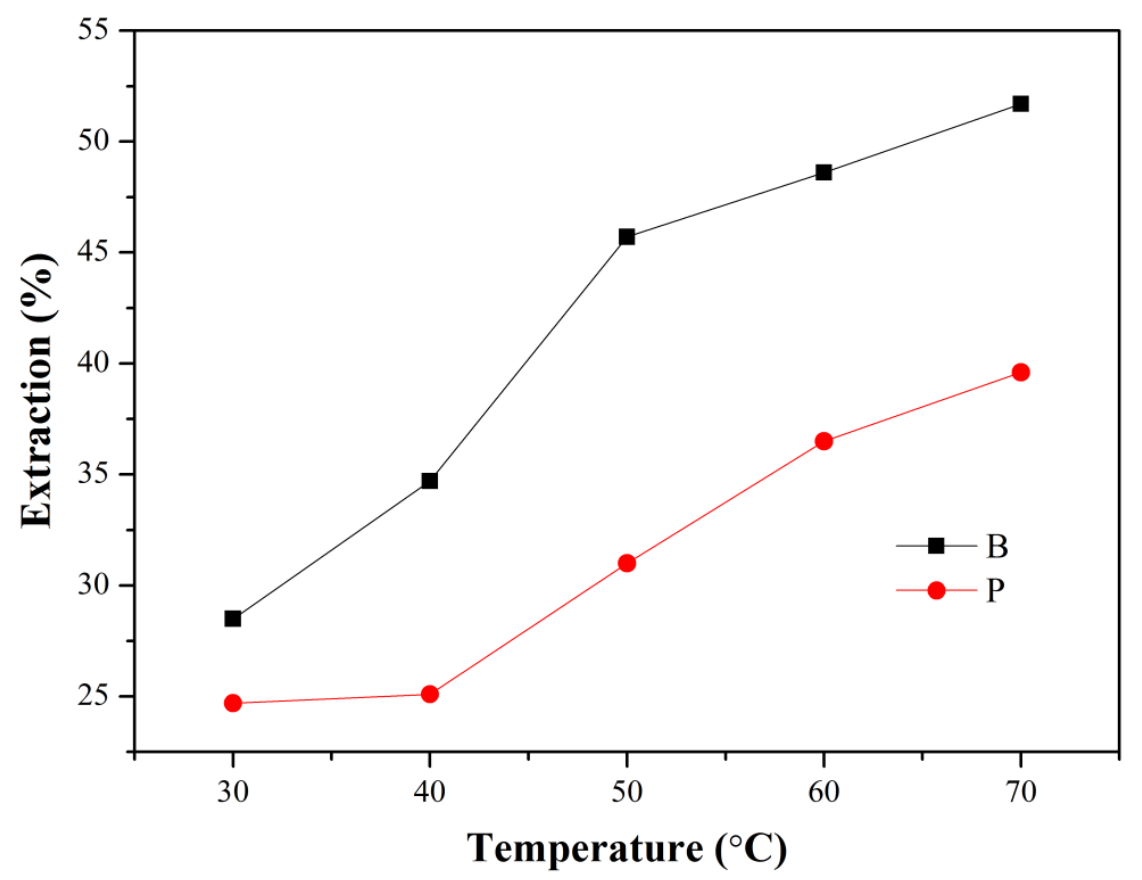

Fig. 8. Effect of the leaching temperature of $\mathrm{Si}-50 \mathrm{wt} . \% \mathrm{Cu}$ alloy on the extraction yield of B and P. Particle size: 74-106 $\mu \mathrm{m}$; initial acid concentration: $2 \mathrm{M}$; time: $5 \mathrm{~h}$; stirring speed: $200 \mathrm{rpm}$. 


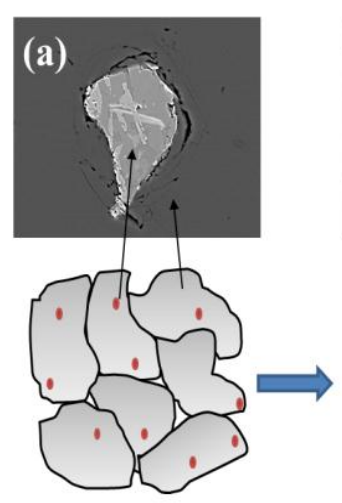

MG-Si

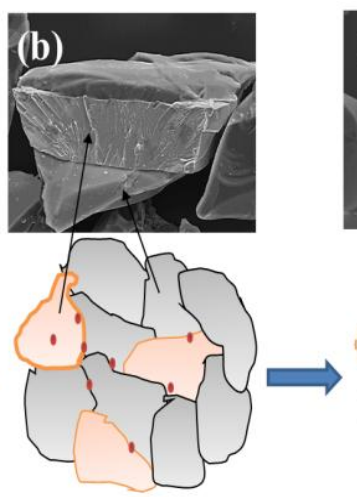

Si-Cu Alloy

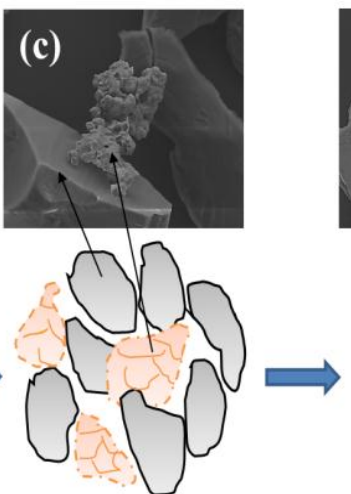

Leached Si-Cu Alloy

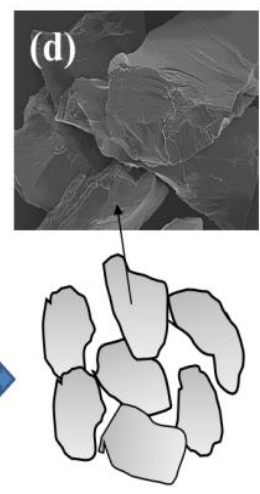

Purified Si

Fig. 9. Schematic illustration of the different stages in the leaching process of the

$\mathrm{Si}-50 \mathrm{wt} . \% \mathrm{Cu}$ alloy according to the modified cracking shrinking model. 


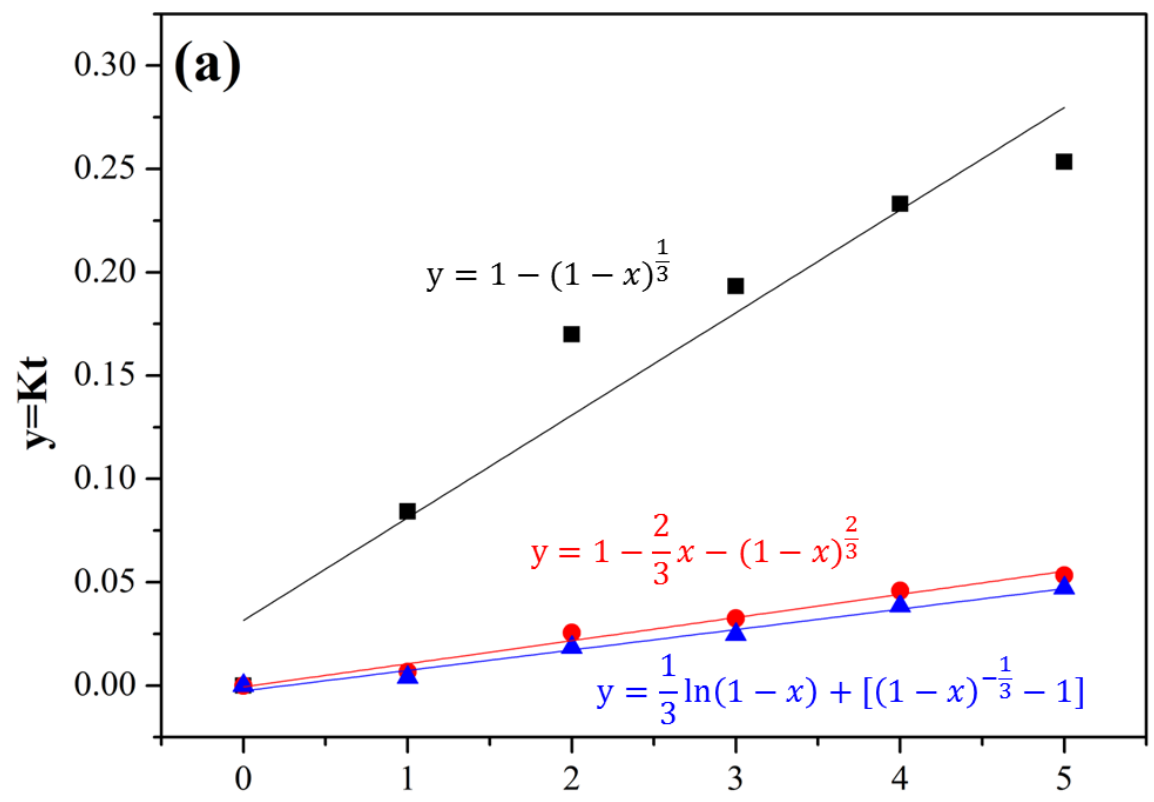

Time (h)

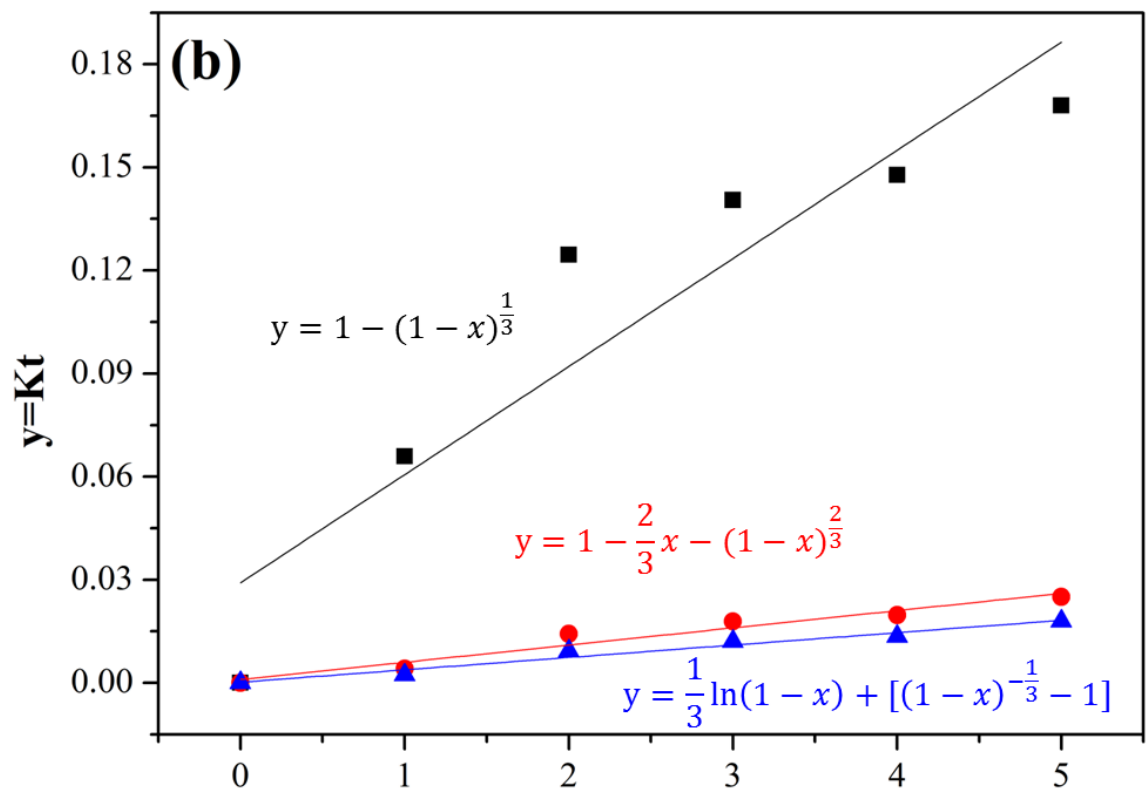

Time (h)

Fig. 10. Application of the modified cracking shrinking model in the acid leaching of Si-50 wt.\% Cu alloy: (a) B and (b) P. 


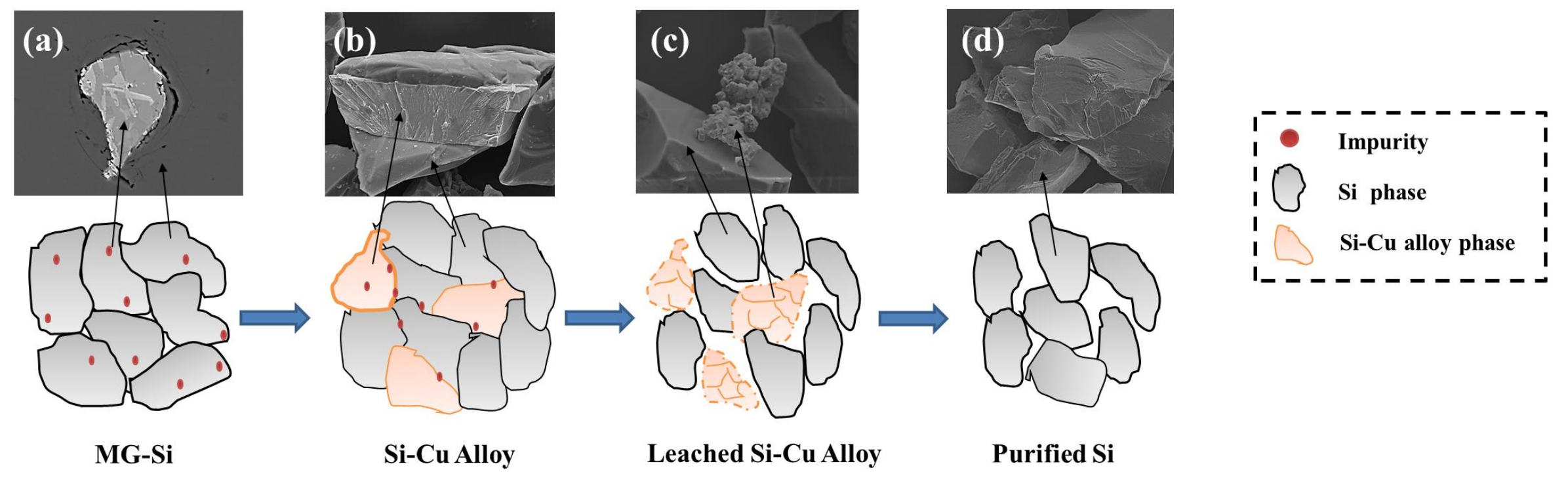

